\title{
Developing Satellite Towns: A Solution to Housing Problem or Creation of New Problems
}

\author{
Md. Mehedi Hasnat and Md. Shamsul Hoque
}

\begin{abstract}
Dhaka, the capital of Bangladesh is the 20th megacity is now the home for over 15 million people. Housing problem for this vast population has become one of the major concerns for this fastest growing mostly unplanned (73\% fully unplanned) megacity of the world. To reduce the pressure of population of Dhaka to a great extent by developing the surrounding area of Dhaka city in a planned way and establishing permanent residence for these vast population two projects were commenced. Purbachal New Town, the biggest planned township of the country and Uttara 3rd phase. Planning of these satellite towns lacks the provisions of introducing modern, futuristic amenities and misses out the concept of sustainable city. In this paper the present major drawbacks of the Dhaka city as it faces due to an unplanned densely populated urban area are pointed out. And along with that the provisions that the new satellite town missed out in their planning are identified. Also modern similar developments around the world are considered and in that regard position of the ongoing new towns are scrutinized. A set of recommendations is provided to make the best use of the available resources, and use our learning from the mistakes that have been made by our progenitor in planning the Dhaka city.
\end{abstract}

Index Terms-Dhaka, housing, megacity, sustainable, unplanned.

\section{INTRODUCTION}

Dhaka, the capital of Bangladesh is the 20th megacity and the most densely populated metropolitan of the world. The city experiences rapid growth of scattered and unplanned development (73\% fully unplanned) without appropriate guidance resulting in immense landuse and transport problems. Lack of buildable land $(75 \%$ are below the natural water level and 95\% within 5 to 7 meters flood level), huge densification (around 45 thousands per sq.km) and mushrooming development of residential (62\%), commercial $(8 \%)$ area and other infrastructure trimmed down the opportunity to construct new roadway infrastructure or to introduce modern system for improving overall transportation system.At present there are only $6.68 \%$ roads of total land area in DMA (Dhaka Metropolitan Area), including 52 percent inaccessible road for motorized vehicles [1].

Dhaka city grew from a rural settlement to become a mega city without much planning effort [2], [3]. Nilufar

Manuscript received August 7, 2014; revised September 18, 2014.

Md. Mehedi Hasnat is with Bangladesh University of Engineering and Technology (BUET), Dhaka-1000, Bangladesh (e-mail: hasnatmehedi@ gmail.com).

Md. Shamsul Hoque is with the Department of Civil Engineering, Bangladesh University of Engineering and Technology (BUET), Dhaka1000, Bangladesh (e-mail: shoque@ce.buet.ac.bd).
(2010) [3] identified four distinct urban patterns in Dhaka, which reflects the age of the city, its rulers, planning philosophy and above all planning control. First is the historical core or 'Old Dhaka' which still contained the Mughal layout of the human scale city. Narrow lanes, very compact buildings, mixed use - all remain the same and remind one of the glorious past. The second category of urban area comprises the formal planned area or satellite towns conceived and planned since 1950. Dhanmodi, Gulshan, Mirpur, Baridhara are examples. It was usual that low lying areas were selected and reclaimed for 'site and services' satellite towns. Until 1980 only RAJUK (RajdhaniUnnayanKartipakhya) was involved in planning and designing for this type of development but now private developers are also providing the same. There is a third category combining the two - a fusion of old and formal patterns - which occupies the most part of development [4]. Shanty towns and small temporary houses fall in fourth category where about $30 \%$ of Dhaka dwellers live [5].

Dhaka is now the home for over 15 million people. Housing problem for this vast population has become one of the major concerns for this fastest growing megacity of the world. To reduce the pressure of population of Dhaka to a great extent by developing the surrounding area of Dhaka city in a planned way and establishing permanent residence for these vast population two huge projects were commenced. Purbachal New Town, the biggest planned township of the country and Uttara 3rd phase. These two projects are ongoing in order to fulfill the following objectives:

- To reduce the pressure of population in Dhaka city by creating opportunity of residential accommodation of the city dwellers in the vicinity of the city.

- To maintain the balance of environment by proper urbanization. To create environment friendly and sustainable atmosphere.

- To reduce the existing acute problem of housing.

- To expand civic facilities by urbanization to the nearby and surrounding areas gradually.

- To mitigate future housing demand.

- Development of new township and to expand economic facilities.

These projects will mitigate the housing problems of the people of the capital, but will fail to provide modern facilities to the dwellers. Planning of these satellite towns lacks the provisions of introducing modern, futuristic amenities and misses out the concept of sustainable city. By not emphasizing on the planning faults of the existing Dhaka city planners failed to assign the much needed facilities in the new towns. 


\section{Methodology}

In this study the planning faults of the present Dhaka city have been identified. In light of those faults the planning flaws of two of the developing satellite towns have been scrutinized. Along with that the present trends in urban sustainable development throughout the world have been incorporated to show the discrepancies to a global context. Regarding the developing towns information have been gathered from existing plans, the progress in developments are identified from site visit and more authentic information have been gathered from the RAJUK planners and implementation team who are involved in the planning and implementation of these two projects.

\section{Project Location ANd PRESENT CONDition}

"Purbachal New Town (PNT) Project" is situated at Rupgonjthana of Narayangonj district and Kaligonjthana of Gazipur district in between river Balu and Sitalakhya at a distance of $16 \mathrm{KM}$ from zero point of Dhaka. The revised project implementation period is July, 1995 to December, 2015. The total area of the Project is 6150 acres which is divided into 30 sectors. Development works have been going on in 4500 acres (Narayangonj part)since 2002-2003 fiscal year and in rest 1500 acres (Gazipur part) development works have been started from January, 2013. At present major implementation problem is land acquisition from the local owners. With the present pace of development work it is uncertain to estimate by what time it will be ready for the people.

"Uttara Residential Model Town (3rd Phase) Project" is situated at a distance about $20 \mathrm{~km}$. from zero point of Dhaka City, Western side of Uttara Model Town (2nd Phase) Project, Northern side of Mirpur Cantonment and East side of Flood Protection Embankment through Mirpur-Ashulia. Under the project about 2150 acres land was acquired. Land development works mostly completed. About 10,000 residential plots, 225,512 apartments with all amenities and urban facilities were provided. The plots will be ready to be handed over by the December of 2014 and the utility works are expected to be finished by the June of 2015 .

\section{Sustainable Urban DeVelopment}

Urban performance currently depends not only on the city's endowment of hard infrastructure but also, and increasingly so, on the availability and quality of knowledge communication and social infrastructure. A city can be defined as 'smart' when investments in human and social capital and traditional (transport) and modern (ICT) communication infrastructure fuel sustainable economic development and a high quality of life, with a wise management of natural resources, through participatory action and engagement [6]. A smart city has:

- a smart economy

- a smart environment

- $\quad$ smart living

On the other hand a sustainable development means a city or town will be sustainable in terms of transportation, energy consumption, public health etc. To identify a development as sustainable one has to ask, will the development:

- Prioritize public transport, cycling and walking, and dissuade the use of cars?

- Ensure accessibility for everyone, including people with disabilities?

- Encourage more efficient use of energy and a reduction in greenhouse gas emissions?

- include the right quality and quantity of public open space

- Include measures to ensure satisfactory standards of personal safety and traffic safety within the neighborhood?

- Present an attractive and well-maintained appearance?

- Promote social integration and provide for a diverse range of household types, age groups and mix of housing tenures?

- Protect, and where possible enhance, the built and natural heritage?

- Provide for Sustainable Drainage Systems?

Throughout the world new growing cities are planning to achieve a sustainable urban development. Putrajaya, Cyberjaya of Malaysia; Chandigarh, Ahmedabad of India are some of the examples of sustainable cities.

\section{Planning Flaws of Purbachal New Town AND UTTARA 3RD PHASE}

\section{A. Landuse}

Town developed for different purposes have different landuse patterns. Provision for sufficient roadway infrastructures, educational institutes, recreational facilities, administrative and physical infrastructures and sufficient open spaces must be integrated at the design phase of any new development project. Around the world planners take inspiration from previous successful developments and try to apply the knowledge on their native context. We also can take a good look on the development projects around the world and try to bring and practice the positive approaches in our socio-economic growth. Putrajaya, a recently developed intelligent city with a 'city in a garden' concept is a good example for any new township development. Several new Governmental administrative centers such as the cities of Washington, D.C (1887), Ottawa (1880), Canberra (1912), Chandigarh (1952) and Abuja (1975) which provide case studies for Malaysian planners to learn from them. Putrajaya was developed as a new administration seat of the Malaysian Government to ensure a quality urban living and environment for the new administrative Centre and to relieve the pressure on Kuala Lumpur's over-stretched infrastructure and also resolved the great shortage of Government land to cater for increased demand for office spaces. On the other hand PNT is mainly a housing project to reduce the ever-growing housing problem for the overwhelming population of the capital. A relative comparison on the landuse patters of Putrajaya and Purbachal New Town is given in Table I.

PNT has higher percentage of residential area which is understandable. But to build a self-sustained city it lacks the other modern and futuristic facilities. It has insufficient open spaces, fewer infrastructures, lacks the implementation of modern utility structures. Initially in 2006 in its first plan 
Purbachal New Town had sufficient amount of open spaces (about $25 \%$ ), but with every renovation the planners reduced the open spaces and converted them into more residential plots. And by the fourth modification the area ended with just $14.76 \%$ of open space. Landuse percentage of the Uttara 3rd phase project include: Residential Plots - 24.01\%,
Highrise apartment block - 10.68\%, Road Network - 30.92\%, Physical \& Social infrastructure - 3.04\%, Lake, Open space \& Park - 13.00\%, Commercial Plots - 5.00\%, CBD $0.92 \%$, Utility Services - $2.53 \%$, Education \& Institution $1.67 \%$ and Neighborhood/Play field $-3.02 \%$.

TABLE I: LAND USE PATTERN OF PUTRAJAYA AND PURBACHAL

\begin{tabular}{|c|c|c|c|c|}
\hline \multirow[t]{2}{*}{ Land use } & \multicolumn{2}{|r|}{ Putrajaya } & \multicolumn{2}{|l|}{ Purbachal } \\
\hline & Acre & $\begin{array}{c}\% \text { of total area(including } \\
\text { roads) }\end{array}$ & $\%$ of total area (excluding roads) & Acre \\
\hline Government & 597.7 & 5.3 & 2.51 & 151.472 \\
\hline Commercial & 327.8 & 2.9 & 5.05(Commercial, Industrial Park) & $210.766+93.98$ \\
\hline Residential & 2888.8 & 25.5 & 38.74 & 2340.2 \\
\hline Civic and cultural & 25.1 & 0.2 & 0.47 & 28.39 \\
\hline Public facilities & 1103.1 & 9.7 & 8.09(Education, Health, Sports, Pedestrian) & 488.7 \\
\hline Infrastructure & 519.2 & 14.2 & 5.49(Social, Physical, Research) & 331.64 \\
\hline Utilities & 1604 & 4.6 & 0.75 & 45.3 \\
\hline Open spaces & 4254.1 & 37.6 & 14.76 & 819.62 \\
\hline Grand Total & $11319.8 *$ & 100 & $76.37 \%+23.63 \%$ for Roads $=100$ & 6040.756 \\
\hline Population Density & \multicolumn{2}{|c|}{ Day time : 41 person/acre } & \multicolumn{2}{|c|}{163 person/acre [STP 2010: Table $14.2-3250$ person/acre] } \\
\hline
\end{tabular}

*Total area 12184.7 acre, Master Plan in 11319.8 acre

This project is planned with an estimated population density equal to 240 people per acre.

Both the new development projects allotted significantly low percentage of land for urban green space and open space. To compensate for the shortage of greenery Chandigarh were planned with the idea of 'green building concept'. No such concept is present in the development of these two projects.

\section{B. Town Planning}

Land use planning outlined in the development plan (structure plan and master plan), besides this there are other planning documents to complement the development control and monitoring of development of any sustainable city. For Putrajaya the planning guidelines are based on comprehensive policies and guidelines in documents namely

- Landscape Master Plan,

- Lake Use and Navigation Master Plan,

- Utilities Master Plan,

- Transportation Master Plan,

- Irrigation Master Plan,

- Lighting Master Plan,

- Urban Design Guidelines,

- Fencing Design Guidelines,

- Signage and Advertisement Design Guidelines

- Local Plans

Among these the plans those should have been integrated with the design of PNT but unfortunately absent are: landscape master plan, Utilities Master Plan, Transportation Master Plan, Lake Use and Navigation Master Plan, Urban Design Guidelines, local plans.

Strict town planning guideline is not exercised in the present Dhaka. As a result diverse use of unplanned growth is encountered in the city. At present more than $75 \%$ of the 4,107 export-oriented garment industries in the country are located in Dhaka. Concentration is also obvious in the social service, trade, commerce, and finance sectors. For example, 48 of the country's 54 private universities established in the last decade are located in Dhaka City. The situation is similar with respect to medical facilities [8].
4000 indiscriminate and unexpected road side garments industries with more than 1 million employees which is generating almost 2.5 million trips per day. Almost 75 percent of those industries are located along the primary roads and the rest are along the secondary roads and creating mammoth adverse impact on the city [9]. Almost 95 percent garments workers go on foot to their work places and walk almost 1 to $1.5 \mathrm{~km}$ per trip [1]. PNT contains two industrial parks, moving some of the garments industries away from the capital will certainly reduce the pressure. The new township in Purbachal does not have any comprehensive town planning master plan yet. This will surely affect the controlled growth of this new township.

Putrajaya has developed the system of Common Utility Trench- securing the utilities inside the tunnel allows a yearround access for the purposes of inspection and maintenance work [7]. In the new towns the utility facilities are more or less like the existing system of DCC. Any kind of utility repair works will hamper the traffic flow as a common utility trench is absent.

\section{Transportation}

In this unplanned city people dwell far away from their working places. As a result everyday huge numbers of citizens have to travel a fair distance of roadway to reach to their working places. According to DHUTS report (2010) [12]:

- A total of 20.8 million trips are made per day by the residents within the Rajuk jurisdiction area.

- 19.6 million trips are produced within the origin in DCC. $91.35 \%$ of 20.8 million.

- Intra-zone trips of DCC (origin and destination within DCC) are 19 million.

- Trips moving between DCC and outside DCC is 0.8 million.

Due to unplanned growth the trips are haphazardly distributed throughout the city.

As found by DHUTS report (2010)[12] major trip attraction zones are:

- Home to Work: ward no 19,33,39,56,36,32,49. Gulshan, Motijheel, Shahbag, Dhanmondi 
- Home to School: ward no 49*,39,57,78, Dhanmondi, Tejgaon, Shahbag, Hazaribag

- Private: ward no 52,49, Newmarket, Dhanmondi

TABLE II: The AVERAGE TRIP LENGTH (KM) BY TRIP PURPOSE IN DCC:

\begin{tabular}{|l|l|l|l|l|l|l|}
\hline & Work & School & Home & NHBB & Private & Total \\
\hline 2009 & 7.7 & 7.6 & 7.7 & 7.7 & 7.4 & 7.6 \\
\hline 2025 & 8.3 & 7.9 & 8 & 8.2 & 7.7 & 8 \\
\hline
\end{tabular}

Source: DHUTS report 2010[12]: Table 12.4-1

The long distance trips for reaching to work and schools are mostly due to unplanned growth. In a planned urban area people dwell close to their working place, within a walking distance in the most perfectly planned areas. Each developed segment has its own schools built within itself during the planning stage. Lacking these far stretching plans people have to travel long distance up and down every day to attend schools. As in the case of Putrajaya a total of 67,000 landed homes, apartments and condominiums are planned, with 3.8 million sq $\mathrm{m}$ of Government and 3.4 million $\mathrm{sq} \mathrm{m}$ of commercial land uses in eight (8) precincts provide shorter journey to work as workplaces and homes are located within the vicinity [7].

It was found that most severe traffic demand will generate along the proposed MRT-6 line. Starting from Uttara 3 and terminating at Tarabo this $29 \mathrm{Km}$ (16Km from Pallabi to Saydabad) long public transport solution will have to carry about 33,900 passenger during the peak hour by the year 2025.Uttara 3rd phase is being developed as home for the people working outside the area. Its plan does not indicate the establishment of a self-sustained city. Distance from Uttara sector 16 to Motijheel is $18.7 \mathrm{~km}$ ! It means people dwelling in Uttara 3rd phase has to make at least 2 trips of $18.7 \mathrm{~km}$ for their living!

Purbachal New Town Project is situated between Baluriver and Shitalakhya river. There are plan of building canals/lake along almost all the sectors. Among this only sector 14 has a dockyard adjacent to the industrial park. Building an integrated waterway to reach different destinations inside and outside the area can significantly reduce the traffic volume in other modes. Integration between different modes of transport is missing in the planning of Dhaka city, which is imparting a heavy toll on the transportation of DCC despite of having a circular water way around the city.

In DCC $19 \%$ of the total trips are made by foot and in DMA this figure is $37.2 \%$ [3]. Pedestrians and their facilities were ignored in the planning of this capital. Footpath availability: Both sides of street $37 \%$, one side of street $19 \%$ and no footpath $44 \%$ of the streets. $39 \%$ of respondents noted that they could not walk where they wanted to, because there was no footpath.

Footpath quality: dirt \& sand 55\%, footpath smooth $18 \%$ and footpath condition fair or poor $82 \%$, worst/bad $79 \%$. Street crossing facilities: police enforcement $1 \%$, signs: $0.6 \%$, foot over-bridge or underpass $0.2 \%$, zebra crossing $0.1 \%$ and no crossing safety $97 \%$ of the streets [10].

Even now necessary importance is not given to the development of pedestrian facilities in DCC. STP allocated only 10 million USD for pedestrians of total budget 5.2 billion USD [10].
In the plan of Uttara 3rd phase over-bridge and underpass for pedestrian are included in the plan, whereas in a planned area safe passage for pedestrian to cross street must be available. Over-bridges or underpasses should not be warranted at the first place. The overall plan consists of 6 over-bridges and 8 underpasses.

Purbachal New Town project has been planned with the provision of $1.56 \%$ (93.978 acre) of the total land for the pedestrians. But proper and safe crossing facilities are still missing in the detailed- plan.

In DCC $38.7 \%$ of the trips are made by NMT (bicycle and rickshaws) in DMA $28.5 \%$ of the trips are made by NMT. The number of bicycle users is increasing remarkably over the past few months. A significant change of trends in commuting among the youths of the city has been going on. "Bdcyclist" a cyclist community of the city has enlisted $17000+$ members after their establishment on 17th May 2011 with a goal to get $5 \%$ of the car owning crowd to start using cycle for their commute by 2014. Yet this sector is neglected. STP allocate only 10 million USD for NMT (Rickshaw; bicycle and other's) of total budget 5.2 billion USD.

Both the Uttara 3rd phase and Purbachal New Town project do not have a segregated bike/NMT route in their plans. Throughout the world planners are highlighting the need of segregated bike lane and safe pedestrian facilities. Amsterdam has $400 \mathrm{~km}$ of bike path [24] for its 1000000 bicycle users. Berlin contains $620 \mathrm{~km}$ of dedicated bicycle lanes, Bogota of Columbia has $300 \mathrm{~km}$ of segregated bike route.

In DCC $28.5 \%$ of the total trips are made by public buses [11].No wonderbuses are the main player of the mass transit system in Dhaka city. less productive intersection $(96 \%$ intersections' phase number are equal to its approach number), lack of loading and unloading facility (except Banani to Uttara), inadequate bus stops, lack of bus lay on road, poor allocation of road space, deficient and improper place of bus terminal (no intra and inter-city interchange facility), lack exclusive right of way, poor enforcement and legislation, indiscipline operation and management etc. the mass transit system is not quite good and seems very difficult to improve in present situation [5]. Such poor and inefficient public transport system also reduces the efficiency of disaster management system which relocates the mass public or provides necessary support within a short time [1].

Over the past decades transportation infrastructures have been built prioritizing private cars. Recent development projects also consists of building more flyovers, elevated expressway, high-rise parking lot, providing more space for parking on road and buildings. This only resulted in increased congestion, pollution, fuel consumption, pedestrian accidents, travel cost-time, social discrimination etc. and national expense for building infrastructures.

Throughout the world the new developing cities are planned to be transit oriented. Great emphasis had been given to public transport and park and ride facilities in the planning of the intelligent city Putrajaya first of its kind in Asia. Transportation planning was done with a 30:70 modal split of private and public transport. 7 park and ride facilities are being developed in different phases in Putrajaya. With a 
day time population density of 41 persons per acre this city has electrically powered urban rail system as the backbone for the public transport infrastructure with a tunnel length of $7.4 \mathrm{~km}$ under construction. To reinforce the rail transit 20 buses were introduced by the year 2005 [12]. In Brazil "Curitiba" has a well-planned and integrated transportation system, which includes dedicated lanes on major streets for a bus rapid transit system. RedeIntegrada de Transporte (also known as RIT, is the Portuguese for Integrated Transportation Network) is a bus rapid transit (BRT) system in implemented in 1974 it notable as being the first of many such systems around the world. Today the system, used by $85 \%$ of Curitiba's population (2.3 million passengers a day) [22], [23]. It has an express rout which takes people into ang out of the city and a local rout which runs within the city. The concept that Brazil used 40 years ago is still missing in Purbachal New Town's present plan.

Transit oriented transportation planning is neglected in the planning of Purbachal New Town and Uttara 3rd phase. Uttara 3rd phase consists of elevated MRT-8 line on the plan. It is uncertain when the line will be constructed and in operation. With an estimated population of density of 240 people per acre (6 times greater than Putrajaya) this part of the city will surely face a transportation disaster without a well-organized mass transit system. On the other hand original plan of Purbachal New Town did not have any LRT/MRT line. One elevated LRT line was added on the later on the plan in response to the "excessive eagerness of the government" according to one of the project implementation manager. According to the planner of PNT LRT/MRT line is unnecessary for such a small city like Purbachal. This city is planned with an estimated population density of 163 people per acre is expected to reach a density of 250 people per acre by the year 2025 [12]. Being short sighted in planning it is inevitable that a time will come when congestion will become just like the present Dhaka city. An integrated public bus service is also absent in the planning of PNT.

\section{Technology}

By 2005, Putrajaya had an estimated population of about 60,000 persons enjoying with modern and smart public amenities and infrastructure. Putrajaya is well equipped with good inter- and intra-city transport system (including monorail and water taxis), broad band width global multimedia communication platform (2.5 to 10 gigabyte fiberoptic digital network), Common Utility Tunnel (CUT) for services, smart hospitals and schools. There were a policy for the development of high-capacity telecommunications and logistic infrastructure, which is built on up to 10 gigabit digital optical fiber backbone and using the ATM switches to provide optical fiber connections to buildings. This network had a five gigabit international gateway with direct links to the US, Europe and Japan as well as the other nations in South East Asia. Today the whole MSC is linked with the world's smart cities with a broadband connection of 27Gbps [13].

Master plan of Purbachal and Uttara 3rd phase do not consist any kind of broadband connections. At present BSCCL (Bangladesh Submarine Cable Company Limited) handles the only submarine cable of Bangladesh. BSCCL participated in Upgrade\#3 of SEA-MEWE- 4 consortium to achieve additional around 6.8 million MIU*km capacity by investing 48 crore taka from its own sources. Additional capacity has already been added with existing capacity and total bandwidth capacity of BSCCL reached to $200 \mathrm{Gbps}$ and whole country is now using 39 Gbpsfrom Submarine Cable. Government has recently awarded licenses to six companies for International Terrestrial Cable (ITC). Companies awarded the license involves Novocom Limited, Asis- AHL JV, BD Link Communication Ltd., Mango Teleservices Ltd., Summit Communications Ltd. and Fibre@Home Limited. ITC establishments are already operational from mid-2013. BSCCL signed the MoU on 28th December 2011 and confirmed its membership in the SMW-5 Consortium. By the 1st quarter of 2015 2nd submarine cable under SMW-5 consortium will be ready for service [14].

\section{E. Utility Facilities}

Among the utility services in Uttara 3rd phase electricity line works is on progress under Dhaka Electricity Supply Co. (DESCO). Electric poles are already erected in sector 15, in sector 16 and sector 17 will be started very soon. Dhaka WASA will execute the work as deposit work and the deep tube well installation and pipe line network will start soon. Gas line installation work will be executed with the consultation with TITAS Gas Co. But still the consent of execution is not yet received from TITAS Gas Co. In Purbachal New Town only the Electric poles are erected at sector 1, 3, 4, 5, 11, 13, 14 \& 17. Installation of electric SubStation at sector 4 should have been started by April'2013, but has not started yet. Both the new towns lack the inclusion of a detailed drainage facility. Dhaka receives about 2,000 $\mathrm{mm}$ of rainfall annually, of which almost $80 \%$ falls during the monsoon. The drains constructed by the Dhaka WASA could pass 60 per cent of the water while the city needs natural drainage to pass the rest 40 per cent rainwater. But the natural drains are either clogged due to poor maintenance or illegally occupied due to lack of strict law enforcement. The drainage capacity of the city has decreased alarmingly. As a result water clogging and frequent flooding have become a regular event during the monsoon season. A $42 \mathrm{~km}$ long man maid canal was proposed to improve the natural drainage of Purbachal New Town. But due to the undulated nature of the land, implementation of the canal will be a very hard task. In some places the existing RL is well above the proposed water level of the canal.

\section{F. Water Quality Status}

A huge pollution load of about $143000 \mathrm{~kg}$ BOD per day in addition to pollution from numerous non-point sources has turned the Balu-Sitalakhya river system virtually into a wastewater conveyance system particularly during the dry season of the year. Available data suggest that the BaluSitalakhya river system is heavily polluted with organic and human wastes, especially during the dry season, as indicated by the low values of DO and high values of Coliform. Since 1989, the DO concentration in the Balu River have been much below the critical level of $4 \mathrm{mg} / \mathrm{l}$; in the Sitalakhya 
River, the DO values have been frequently below $4 \mathrm{mg} / \mathrm{l}$ since 1997 . Similar low DO values are also reported by IWM [15]. BUET [16] reports much lower value of DO of around $3.0 \mathrm{mg} / \mathrm{L}$ in Sitalakhya River during February-March and less than $1.0 \mathrm{mg} / \mathrm{L}$ in waters of Begunbarikhal during the same period. Relatively high ammonia was detected in both Balu and Sitalakhya Rivers. High concentration of ammonia in water is usually an indication of bacterial, sewage, and animal waste pollution. Measured data suggest that the Noraikhal is the most probable source of ammonia in the Balu river system while high ammonia concentration has been reported by BUET in Sitalakhya near Sarulia intake point. Such low values of DO reflect gross pollution of the river system, a situation where aquatic lives cannot sustain and the water becomes unsuitable for any intended purpose including potable water supply source [17].

Purbachal New Town is situated in between the Baluriver and Sitalakhya river is surely going to be affected by the pollution. It will accommodate two industrial park with their own industrial waste treatment plant which will dispose the treated waste water into the Baluriver. There are no comprehensive planning about controlling the pollution of these two rivers will only add to the pollution problems. In this context we can learn from Putrajaya, where wetlands have been constructed to remove pollutants from the catchment before it enters the lake. Study revealed presence of increased pollutant levels in the lake's water from upstream sources and outside the city's development boundary just like the case of Purbachal New Town where the lake's upstream source is the Baluriver. Hence sustaining the long-term urban development of the wetlands is proposed with the aim "to create a self-sustaining and balanced ecosystem in Putrajay" [18]. A total of 24 wetlands cells are being created based on the height of the water level, each of which are designed to create zones of wetland and intermittent inundation.

\section{G. Waste Water Treatment and Solid Waste Management}

Solid waste management and waste water treatment are big issues in a planned urban development. In both the new development authorities are trying to get these jobs done by PPP (Public Private Partnership) initiatives. Uttara 3rd phase the waste water will be treated in sector 18 , also a 10 acre area is designated for recycling of solid waste in sector 18 . In Purbachal New Town the proposed light industrial areas will have their own industrial waste water treatment plant and the treated water will be disposed in adjacent lakes. The solid waste dumping station and central compositing plant is situated at block H-4. At present solid waste management is an alarming issue for the residents of Dhaka city. Rapid and unplanned urbanization makes Dhaka one of the top ranked high-risk cities in the world [19]. In According to Hasan and Chowdhury [20], $50 \%$ of the daily generated waste remains uncollected in the city. Disposing of waste in open dumps is the most common method used for final disposal of urban solid waste. The only one sanitary landfill site located at Matuail has an area of 40 hectares [19]. Presently an estimated 7,000 tons of MSW is generated daily in the Dhaka City of which only 1200-1500 tons is disposed in the landfills and the rest left unattended or locally dumped [20]. It is estimated that existing sites will fill up shortly and DCC will have to arrange for new dumping sites for waste disposal. With per capita solid waste generation of $0.5 \mathrm{~kg} /$ day [21] estimated solid waste generated will be 258 ton/day and 767 ton/day for Uttara 3rd phase and Purbachal New Town respectively. Establishing a settlement to treat such a huge quantity of solid waste will require fair amount of time. So the process should begin now at this instance to ensure quality service when the demand is reached.

\section{RECOMMENDATIONS}

To make the Purbachal New Town project and Uttara 3rd phase project a grand success certain measures must be taken at once. Therefore some recommendations are provided below:

- To compensate the low percentage of green area concepts like "green building concept" can be adopted to ensure a fair percentage of greenery is present in the new developed areas.

- In Purbachal New Town a fair amount of open spaces have already been transformed into residential plots. The remaining 819.62acre area must be preserved at any cost. If possible the amount should be increased for healthy living of the citizens.

- Landscape master plan, Utilities Master Plan, Transportation Master Plan, Lake Use and Navigation Master Plan, Urban Design Guidelines and local plans should play an integrated role in the full-fledged growth of the two new development projects. These plans must be developed in collaboration with the different ministries of the government as soon as possible.

- A detailed form work of the transportation must be formed prioritizing public transport. Increasing importance should be given in developing bicycle lane and pedestrian friendly road network, making a comprehensive plan that will be ready to be implemented at the very beginning of the infrastructure development.

- Provision for fiber optic connection must be present at the beginning of infrastructure development. This will work as technological base which will make the life more upto-date and help in reducing the traffic demand.

- As part from the utility connection and management a common utility trench is the latest solution available. This idea should be adopted and implemented.

- A careful significance should be given in keeping the river at both side of the Purbachal New Town pollution free. To control the present extent of pollution steps should be taken at once.

- Before people start to live in the net satellite towns a sustainable solution of waste water treatment and solid waste management must be sorted out. Scope of solid waste recycling may also be taken under consideration.

- Overall a definite goal should be set and phased development must be ensured to meet the deadline. In 
developing the projects RAJUK should work as an independent organization.

\section{CONClusion}

For a densely populated country like Bangladesh scope for new development is very limited. The developed countries with vast open spaces and even the developing countries with much less densely populated areas have the scope of experimenting with new township development. But for an already built up area like Dhaka city it is very hard to acquire free land at the periphery to expand the city.Under the present situation the on-going projects are like do or die situation for the government. Ruining the opportunity will be an utter and irreversible mistake. Hence significance must be given to integrate the land use, transportation, urban design and local plans to make these projects an example for future development. The open spaces and the water bodies must be preserved. Sustainable solution to waste water treatment and solid waste management must be incorporated in the satellite towns at once. This is high time that the city development authority work independently to make the projects a grand success.

\section{REFERENCES}

[1] S. M. M. U. N. M. Hashem. Trends of Development in Dhanmondi. [Online].

Available: http://www.bip.org.bd/SharingFiles/journal_book/20130718115659.p df

[2] K. Nahrin. Violation of Land Use Plan and Its Impact on Community Life in Dhaka City. [Online]. Available: http://www.bdresearch.org.bd/home/attachments/article/595/jp4a5d71 2cc08eb.pdf

[3] A. Islam, Term Paper, Junior Transport Consultant, Dhaka Transport Co-ordination Board (DTCB).

[4] M. Sultana, Dhanmondi no More What it was. [Online]. Available: http://www.thefinancialexpress-bd.com/more.php?news_id=46246

[5] C. F. Choudhury, M. Khan, and J. Wang, "Modeling preference for school bus service in Dhaka: an SP based approach," Department of Civil Engineering, Bangladesh University of Engineering and Technology, Harvey Mudd College.

[6] T. Khan, M. S. Hoque, and A. S. Huq, "Investigating the prospect of introducing traffic management measures in Dhaka city," Department of Civil Engineering, Bangladesh University of Engineering and Technology, Dhaka, Bangladesh.

[7] Impacts Monitoring; Sixth Annual Report. [Online]. Available: http://www.tfl.gov.uk/assets/downloads/sixth-annual-impactsmonitoring-report-2008-07.pdf

[8] N. Chris, "Road pricing in Britain," Journal of Transport Economics and Policy, vol. 41, no. 137, 2006.

[9] Transport for London. Transport for London Homepage. [Online]. Available: http://www.cclondon.com/

[10] The Success of Stockholm's Congestion Pricing Solution. [Online]. Available: http://www.thisbigcity.net/the-success-of-stockholmscongestion-pricing-solution/

[11] R. Bain and J. W. Plantagie, "The credit dynamics of congestion charging," Financial Report, New York: Standard and Poor's, USA, 2003.

[12] CIA World Factbook, 2013.

[13] B. Ahmed, "Congestion charging scheme for the city of manchester: lessons learnt," Transportation Research Group, School of Civil Engineering and the Environment, University of Southampton, Highfield Southampton, SO17 1BJ, United Kingdom, January 2011

[14] A. Eberline. Cost/Benefit Analysis of Electronic License Plates. [Online]. Available: http://cebcp.org/wpcontent/lpr/ArizonaCostBenefitAnalysis.pdf

[15] Australian Transport Council (ATC), National Guidelines for Transport System Management in Australia: Urban Ttransport, vol. 4. Canberra: ATC, 2006.

[16] A. Eberline. Cost/Benefit Analysis of Electronic License Plates. [Online]. Available: http://www.cebcp.org/wpcontent/lpr/ArizonaCostBenefitAnalysis.pdf

[17] Preparatory Survey Report on Dhaka Urban Transport Network Development Study (DHUTS) in Bangladesh, 2010.

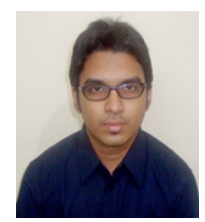

Md. Mehedi Hasnat is an undergraduate student in the Department of Civil Engineering in Bangladesh University of Engineering and Technology (BUET). He is currently doing his research on "Reducing Congestion in Dhaka City" under the supervision of Dr. Md. Shamsul Hoquefor the completion of his B.Sc. Engg. Degree.

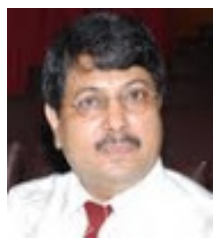

Md. Shamsul Hoque received his B.Sc. degree in civil engineering in 1984 from BUET and he received his M.Sc. degree in transportation engineering from the same university in 1987 and $\mathrm{PhD}$ in 1995 from University of Southampton, UK. The title of his $\mathrm{PhD}$ thesis was "Modeling of Signalized Intersection in Developing Countries". Now he is a professor and in-charge of transportation engineering division at the Department of Civil Engineering, BUET. He is the former director of accident research institute (ARI) and former test-in-charge, Bureau of Research, Testing and Consultation (BRTC) of Department of Civil Engineering, BUET. 